\title{
Comment
}

\section{Progressive Law and Economics- And the New Administrative Law}

\author{
Susan Rose-Ackerman $\dagger$
}

\section{INTRODUCTION}

Economics: the dismal science. But surely this insults the messenger who brings the bad news. Economic method is not dismal, unless the mere sight of mathematics and statistics makes you depressed. Economics tries to reveal the costs in time, money, and energy of all of life's enterprises; it refuses to permit dreamers to ignore scarcity. But if resources really are scarce, are we better off ignoring the truth?

This question is of greater importance for progressives than conservatives. While conservatives can oppose government regulatory and spending programs "on principle," a credible progressive movement must weigh the costs as well as the benefits of reform. It is, then, odd and unfortunate that law and economics is often associated with a set of conservative ${ }^{1}$ and, to many, morally dismal ideologies that have no intrinsic connection to the economic analysis of legal problems. This Comment urges the development of a reformist law and economics, ${ }^{2}$ closely linked to administrative

\footnotetext{
† Ely Professor of Law and Political Economy, Yale University.

1. For an example of polemical writing that encourages the popular association of law and economics with the political right, see McConnell, The Counter-Revolution in Legal Thought, 48 PoL'Y Rev. 18, 23-24 (1987). Although McConnell admits that law and economics "has no overt ideological element," he nevertheless claims that "law and economics scholars will-with only rare exceptions-take positions comparable with libertarian conservatives." Id. at 23-24.

2. This proposal is not without precedent. Many of the earliest law and economics scholars were liberal reformers. See L. Kalman, Legal Realism at Yale: 1927-1960 (1986). In the Federal Republic of Germany, law and economics has a reformist emphasis. See H. SCHAFFER \& C. OTT, ÖKONOMISCHEN ANALYSE DES ZTVILRECHTS (1988) [forthcoming].
} 
law and based on public finance theory, public policy analysis, and social choice theory.

With the fiftieth anniversary of the Administrative Procedure Act $^{3}$ on the horizon, this is a propitious time for reconsidering the law of the administrative state. On the one hand, the postwar period has seen an explosion of new learning on both the economic analysis of policy issues and the political-economic evaluation of government processes. On the other hand, changes in the law have forced both judges and legal scholars to reexamine the roles of Congress, agencies, and courts. Laws regulating environmental pollution, safety, and health cut across a broad range of industries and involve complex scientific and social questions which raise new issues of public accountability and competence in all branches of government. Together, these joint developments in the world of ideas and the realm of practical politics and policy suggest the promise of a law and economics scholarship based on the insights of political economy.

This new direction is at odds with three dominant strands of law and economics. The first, associated with the University of Chicago, takes wealth maximization as a first principle, viewing it as a happy compromise between utilitarianism and free choice. ${ }^{4} \mathrm{~A}$ second emphasizes the key role of stable, well-defined property rights in promoting efficiency and economic growth. ${ }^{8}$ A third, the Virginia School, employs public choice theory in a constitutional framework to demonstrate the failings of government. ${ }^{8}$ Scholars in all three traditions are skeptical about the legitimacy of legislative and bureaucratic processes and share a confidence in the value of market outcomes. ${ }^{7}$

Critiques of these three schools are a familiar feature of the academic scene. $^{8}$ I have contributed elsewhere ${ }^{\vartheta}$ and will not repeat my arguments

3. 5 U.S.C. $\$ \S 551-559$ (1982). See The Administrative Procedure Act: A Fortieth Anniversary Symposium, 72 VA. L. Rev. 215 (1986).

4. See, e.g., R. Posner, Economic Analysis of Law (3d ed. 1986); R. Posner, The EcoNOMICS OF JUSTICE 48-82 (1981). But wealth maximization apparently is not the only principle worth considering. See Posner, The Effects of Wealth Maximization: Reply to Malloy, 36 U. Kan. L. REv. 261, 264 (1988).

5. See Demsetz, Toward a Theory of Property Rights, in The Economics of Legal. Reilationships: Readings IN THE TheORY OF Property Rights 23 (1975); Furubotn \& Pejovich, Property Rights and Economic Theory: A Survey of Recent Literature, in id. at 53; Pejovich, Specification of Property Rights, in id. at 32; Stubblebine, On, Property Rights and Institutions, in id. at 11; see also Staaf, Property Rights and Choice, in Law And Economics 175 (N. Mercuro ed. 1989) [forthcoming] [hereinafter LAW AND ECONOMics].

6. See J. Buchanan, The Limits of Liberty: Between Anarchy and Leviathan (1975); J. Buchanan \& G. Tulluck, The Calculus of Consent (1962); G. Tullock, Trials on Trial (1980); Rowley, Public Choice and the Economic Analysis of Law, in LAw AND Economics, supra note 5, at 123; see also, Symposium on the Theory of Public Choice, 74 VA. L. REv. 167 (1988) (collection emphasizing Virginia approach).

7. A fourth school has had little impact on legal thought. This is the view espoused by Gary Becker that all law is optimal. Given transaction costs, all political and economic deals that are worth making are, in fact, made. Becker, $A$ Theory of Competition Among Pressure Groups for Political Influence, 98 Q. J. EcoN. 371 (1983).

8. For critiques by noneconomists, see B. ACKERMan, ReCONSTRUCTING AMERICAN LAW 80-93 (1983); Kelman, Consumption Theory, Production Theory, and Ideology in the Coase Theorem, 52 S. 
here. Instead, Section II of this Comment takes up the constructive task of outlining a reformist political economy of law that operates within the basic paradigms of economic theory and builds on the work of noneconomists currently active in the public law field. ${ }^{10} \mathrm{My}$ object is to promote the reform of public law, not the sanctification of the common law tradition. After linking political economy to work in administrative law, Section III proposes a statute that envisions a new role for the courts in reviewing legislation. Section IV evaluates occupational health and safety policy from the perspective of the Congress, the agencies, and the courts. The conclusion suggests how research on administrative law can productively combine the detailed study of particular policy issues with a broader political-economic perspective.

\section{The Reformist SchOOL}

A reformist law and economics denies the primacy of the existing distribution of property rights while retaining the assumption of methodological individualism that is central to the economic approach. From this base, reformist analysis looks in two directions: toward public policy analyses designed to improve the efficiency of the economy, and toward work in public choice that seeks procedures to resolve distributive issues fairly. Students of each approach rarely take each other seriously. This intellectual isolation should be overcome to produce a unified scholarship drawing on both traditions. This section begins, however, by sketching the basic features of each perspective.

\section{A. The Public Policy Framework}

Public policy analysis is based on welfare economics, which emphasizes externalities and market failures, and the theory of imperfect competition, which focuses on the inefficiency of monopoly power, imperfect informa-

Cal. L. Rev. 669 (1979); Kelman, On Democracy-Bashing: A Skeptical Look at the Theoretical and "Empirical" Practice of the Public Choice Movement, 74 VA. L. REv. 199 (1988); Kennedy \& Michelman, Are Property and Contract Efficient?, 8 Hofstra L. Rev. 711 (1980); Leff, Economic Analysis of Law: Some Realism About Nominalism, 60 VA. L. Rev. 451 (1974); Shapiro, Richard Posner's Praxis, 48 Orio ST. L.J. 999 (1987). For critiques by economists, see Kornhauser, A Guide to the Perplexed Claims of Efficiency in the Law, 8 Horstra L. REv. 591 (1980); Polinsky, Economic Analysis as a Potentially Defective Product: A Buyer's Guide to Posner's Economic Analysis of Law, 87 HaRv. L. REv. 1655 (1974).

9. Rose-Ackerman, Tullock and the Inefficiency of the Common Law, in DEMocRACY AND PUBlic Choice: Essays in Honor of GoRdon Tullock 181 (C. Rowley ed. 1987); Rose-Ackerman, Dikes, Dams, and Vicious Hogs: Entitlement and Efficiency in Tort Law, 18 J. LEG. STUD. (1989) [forthcoming]; Rose-Ackerman, Law and Economics: Paradigm, Politics or Philosophy, in LAW AND Economics, supra note 5, at 233; Rose-Ackerman, Recht und Öhonomie, in H. SCHAFFER \& C. OTT, supra note 2; Rose-Ackerman, Book Review, 8 J. Pol'Y \& MGMT. 726 (1988) (reviewing W. Landes \& R. Posner, The Economic Structure of Tort Law (1987)).

10. See infra notes 29-30. My approach is also complementary to the work of such neoinstitutionalists as Oliver Williamson. See O. Williamson, The Economic INSTITUTIONS OF CaPITALISM (1985). 
tion, and monopolistic competition. The level of analysis is the market or, in cost-benefit analyses, the public program. The underlying philosophy is utilitarianism or wealth maximization with an egalitarian side constraint. ${ }^{11}$

Work on public policy is basically optimistic about politics, viewing government as a system which designs and implements policies to improve the efficiency and equity of society. Economists and lawyers working in the field see themselves as central to policy development, producing costbenefit analyses and other useful analytic exercises. They are similar to Chicagoans in recognizing the value of markets in promoting efficiency and the importance of economic incentives in both the private and public sectors. They are trying to get the economic incentives right, not eliminate them.

A fundamental methodological difference, however, separates the two approaches. Chicagoans concentrate on common law courts, which typically rule on individual transactions. ${ }^{12}$ Of course, the decision in one case may affect behavior in future similar situations, but the emphasis is on affecting individual behavior, not reforming market structures. ${ }^{13}$ In contrast, students of public policy look to the legislature and the executive branch as the institutions in which basic policy changes originate. This perspective invites a more comprehensive view of the overall effect of policy on markets.

However, public policy analysis generally lacks a realistic view of the workings of the political process. With very few exceptions, ${ }^{14}$ the work represents the best advice an economist can give to a policymaker, ignoring political feasibility or, rather, leaving the politician or top bureaucrat with the task of linking the economic prescriptions with political reality.

\section{B. Public Choice}

Public choice theory attempts to provide realistic positive models of politics and to find methods of making collective choices that have desirable normative characteristics. The positive analysis tries to explain how political and bureaucratic bodies actually behave by assuming that the political actors are self-interested maximizers of something (e.g., votes,

11. Standard works include R. Musgrave \& P. Musgrave, Public Finance in Theory and Practice (4th ed. 1984); A. Okun, Equality and Efficiency: The Big Tradeoff (1975); E. Stokey \& R. Zeckhauser, A Primer for Policy Analysis (1978); and D. Weimer \& A. ViNing, Policy Analysis: Concepts and Practice (1988).

12. For an overview of law and economics from this perspective, see Kornhauser, Legal Rules as Incentives, in LAW AND ECONOMrcs, supra note 5, at 28. See also Rose-Ackerman, Law and Economics: Paradigm, Politics or Philosophy, supra note 9, at 233.

13. See R. Posner, Economic ANAlysis of LAw, supra note 4, at 249-428.

14. See, e.g., Hahn \& Noll, Designing a Market for Tradeable Emission Permits, in ReForM of Environmental Recul.ation 39 (W. Magat ed. 1982); Levine, Revisionism Revised? Airline Deregulation and the Public Interest, LAW \& CONTEMP. ProBs., Winter 1981, at 179. 
agency budgets, profits, utility). It then evaluates the agency-principal problems and strategic behavior concerns central to representative democratic government and to the performance of bureaucracies. The normative analysis specifies desirable conditions for collective choice procedures and seeks decision processes that satisfy these conditions. The two approaches overlap since many abstract normative problems associated with collective choice also arise in any decisionmaking body that makes choices by aggregating individual preferences.

Modern normative work began with Kenneth Arrow's Impossibility Theorem. ${ }^{15}$ Arrow specified a set of obviously attractive and seemingly minimal normative conditions and then proved that no social choice process could satisfy all of them. ${ }^{16}$ The theorem can be seen as formal proof that economics cannot be a universal science of political-economic life. Arrow also provoked a line of research that produced constructive results of more limited scope. Scholars began a fuller analysis of the normative properties of various voting rules ${ }^{17}$ and demonstrated the pervasiveness of incentives for strategic action. ${ }^{18}$

Positive, institutionally-oriented work has modelled the behavior of representative assemblies and bureaucracies and analyzed individual political behavior. ${ }^{19}$ Recent research stresses the importance of legislative procedural rules, such as committee structure and amending procedures, in affecting the ultimate legislative outcome. ${ }^{20}$ If, for example, a majority-rule

15. K. Arrow, Social Choice and Individual Values (1951 \& 2d ed. 1963).

16. Arrow was seeking a social ordering that, like individual preferences, is transitive, complete, and reflexive. The social ordering must not place any other restrictions on individual preferences. The resulting rule must be efficient in the sense that if everyone finds option $\mathrm{A}$ at least as good as option $\mathrm{B}$ and at least one person prefers $A$, then $A$ should be the social choice. No one can be a dictator whose preferences always determine the social outcome, and a condition called independence of irrelevant alternatives must hold. This condition states that the social choice between A and B depends only upon how A and B are ranked by individuals. The ranking of other options is irrelevant. In a world with more than two mutually exclusive options, no social ordering can be found which satisfies these conditions. Id. at 46-60.

17. Some of the seminal work was written at about the same time as Arrow's proof. The classic article on the normative properties of majority rule is May, A Set of Independent, Necessary, and Sufficient Conditions for Simple Majority Decision, 20 Econometrica 680 (1952). On the characteristics of preferences needed for consistent majority choice, see D. BLACK, A THEORY OF CoMMITTEES AND Elections (1963). For reviews of work in this field, see J. BONNER, INTRODUCTION TO the Theory of Social Choice (1986); A. Feldman, Welfare Economics and Social. Choice Theory 196-215 (1980); D. Mueller, Public Choice (1979); P. Ordeshook, Game Theory and Political Theory (1986); and A. Sen, Collective Choice and Social Welfare (1970).

18. See Gibbard, Manipulation of Voting Schemes: A General Result, 41 Econometrica 587 (1973); Satterthwaite, Strategy-Proofness and Arrow's Condition: Existence and Correspondence Theorems for Voting Procedures and Social Welfare Functions, $10 \mathrm{~J}$. EcoN. THEORY 187 (1975); see also A. FELDMAN, supra note 17, at 196-215 (nontechnical overview).

19. See, e.g., J. Ferejohn, Pork Barrel Politics (1974); M. Fiorina, Congress: Keystone of the Washington Establishment (1977); D. Mayhew, Congress: The Electoral CoNNECTION (1974); Shepsle, The Positive Theory of Legislative Institutions: An Enrichment of Social Choice and Spatial Models, 50 PUB. Chorce 135 (1978). The foundations of this research were laid by economists. See A. Downs, An Economic Theory of Democracy (1957); M. Olson, The Logic of Collective Action (1965).

20. See, e.g., P. ORDESHOOK, supra note 17; Gilligan \& Krehbiel, Collective Decisionmaking and Standing Committees, 3 J. L. EcoN. \& ORG. 287 (1987); Krehbiel, Sophisticated Committees and 
legislature binds itself to take final votes that compare proposed changes with preexisting legal rules, this procedure limits the laws that can be adopted. Without such a constraint, the outcome might be almost anywhere in the space of possible alternatives. After a series of votes on amended bills, the majority might not prefer the final statute to the status quo which existed before the legislature began work. ${ }^{21}$

Researchers have also modelled how a government bureaucracy affects legislative choices both at the drafting stage and at the budgetary appropriations stage. Some argue that legislators design laws so that they contain numerous opportunities for "casework." After such laws are on the books, a legislator can benefit her constituents by intervening in their favor with the bureaucracy. ${ }^{22}$ Other work suggests that the extent of congressional delegation to the executive branch depends upon whether benefits and costs are concentrated or diffused. If benefits are diffused and costs are concentrated, Congress is likely to prefer shifting the difficult choices to an agency. ${ }^{28}$ Finally, research on the budgetary process shows how an agency's control over program information and over the allocation of funds can be used to increase or maintain budgetary appropriations. ${ }^{24}$

Most of this positive work is skeptical about the normative claims for democratic government. Self-interested, vote-maximizing behavior does not seem broadly compatible with the production of efficient public policies. ${ }^{25}$ Skepticism, however, need not lead to conservatism or the espousal of minimal government. ${ }^{28}$ After all, private institutions, be they corporations, families, or voluntary organizations, also disappoint idealists. In practice, much normative work in public choice is almost radical, arguing that the distribution of property and privilege produced by the market and other nongovernmental institutions should not be given weight by the political system. One reason majority rule appeals to normative theorists is

Structure-Induced Equilibria, in Congress: Structure and Policy 346-75 (M. McCubbins \& T. Sullivan eds. 1976); Levine \& Plott, Agenda Influence and Its Implications, 63 VA. L. Rev. 561 (1977); Shepsle, Institutional Arrangements and Equilibrium in Multidimensional Voting Models, in Congress: Structure and Polic:y, supra, at 376-402.

21. Shepsle \& Weingast, When Do Rules of Procedure Matter?, 46 J. PoL. 207 (1984).

22. Fiorina \& Noll, Voters, Legislators, and Bureaucracy: Institutional Design in the Public Sector, 1978 Am. Econ. Rev.- Proc. \& Papers 256.

23. Fiorina, Group Concentration and the Delegation of Legislative Authority, in ReGul.ATORY Policy ANd THE Social Sciences 175 (R. Noll ed. 1985).

24. R. Arnold, Congress and the Bureaucracy (1979); W. Niskanen, Bureaucracy and REPRESENTATIVE GovernMENT (1971).

25. See, e.g., Rose-Ackerman, Inefficiency and Reelection, 33 Kykzos 287 (1980); Stigler, The Theory of Economic Regulation, 2 BELL J. ECON. 3 (1971). Work in this skeptical tradition is summarized in Farber \& Frickey, The Jurisprudence of Public Choice, 65 TEx. L. REv. 873 (1987). In a second article, however, these authors reference recent work suggesting that consistency (if not efficiency) is possible in a range of plausible situations. Farber \& Frickey, Legislative Intent and Public Choice, 74 VA. L. Rev. 423, 432-33 (1988); see also P. ORdeshook, supra note 17, at 144, 202.

26. See, e.g., A. SEN, On ECONomic INEQuality (1972); Sen, Rational Fools: A Critique of the Behavioral Foundations of Economic Theory, 6 PhIL. \& PUB. AfF. 317 (1977). 
that even the status quo must obtain majority support in order to survive. ${ }^{27}$

\section{The Reform of Administrative Law}

Reformist law and economics combines public policy and public choice to redirect the study of administrative law. Unfortunately, most economists in law schools have not made this connection. They concentrate on the common law fields of tort, contract, and property, or, drawing on a tradition of economically-informed legal scholarship, focus on antitrust, public utilities, and trade regulation..$^{28}$ In the absence of interest from economists on law faculties, a number of noneconomists in administrative law have begun to creatively use both public policy ${ }^{29}$ and public choice. ${ }^{30}$ Even so, American administrative law remains a court-centered field focusing on judicial review of agency behavior. ${ }^{3 x}$ So long as courts remain at the center, the majority of legal commentators can ignore issues related to economic efficiency and political choice. Thus, an awkward fit exists between public policy analysis and the traditional concerns of administrative law. While economists are not well-informed about institutional, bureaucratic realities and are especially ignorant of the courts, most lawyers are accustomed to focusing on procedural issues and the role of lawsuits in producing change, but do not fully understand the underlying economic and political issues.

Despite the narrow concerns of conventional work in administrative law, public choice scholars can provide analyses of bureaucratic and legislative institutions that are directly relevant to judges concerned with pro-

27. This condition, called the "neutrality condition," requires that no option, including the status quo, has any special priority under the social decision rule chosen. See May, supra note 17.

28. This work is sometimes called the "old" law and economics to contrast it with the new law and economics of the common law. See Rowley, supra note 6; Veljanovski, The Role of Economics in the Common Law, 7 Res. L. \& Econ. 41 (1985).

29. For representative samples of this work, see B. ACKerman \& W. Hassler, CleAN CoAl/ DirTy AIR (1981); S. BREYER, REgulation AND ITS REFORM (1982); Bruff, Legislative Formality, Administrative Rationality, 63 TEx. L. REv. 207 (1984); Diver, Policymaking Paradigms in Administrative Law, 95 Harv. L. Rev. 393 (1981); Mashaw, Administrative Due Process as Social Cost Accounting, 9 Hofstra L. Rev. 1423 (1981); Rabin, Administrative Law in Transition: A Discipline in Search of an Organizing Principle, 72 Nw. U.L. REv. 120 (1977); Stewart, The Reformation of American Administrative Law, 88 HaRv. L. REv. 1667 (1975); and Sunstein, Factions, SelfInterest, and APA: Four Lessons Since 1946, 72 VA. L. REv. 271 (1986).

30. Public choice material is used in Cass, Looking with One Eye Closed: The Twilight of Administrative Law, 66 B.U.L. Rev. 1 (1986); Debow \& Lee, Understanding (and Misunderstanding) Public Choice: A Response to Farber E् Frickey, 66 TEx. L. REv. 993 (1988); Farber \& Frickey, Integrating Public Choice and Public Law: A Reply to DeBow and Lee, 66 Tex. L. Rev. 1013 (1988); Farber \& Frickey, The Jurisprudence of Public Choice, supra note 25; Farber \& Frickey, Legislative Intent and Public Choice, supra note 25; Levine \& Plott, Agenda Influence and Its Implications, 63 VA. L. REv. 560 (1977); Macey, Promoting Public-Regarding Legislation Through Statutory Legislation: An Interest Group Model, 86 Colum. L. REv. 223 (1986); and Spitzer, Radio Formats by Administrative Choice, 47 U. CHI. L. REv. 647 (1980).

31. See, for example, even those casebooks that draw most heavily on the social science literature in infra note 35. 
cedural fairness. In practice, however, these links have seldom been made. There are two explanations for this. First, judges have been reluctant to evaluate the structure of the legislative process ${ }^{32}$ and too often have assumed that bureaucracies should act like courts.

Second, a few Chicago School efforts have thus far dominated the relevant legal scholarship, using public choice to buttress their court-centered approach. In this interpretation, public choice merely emphasizes the impossibility of consistent political choice and the pervasiveness of strategic manipulation in representative assemblies and bureaucracies. ${ }^{33}$ Given this bleak assessment of political life, the emphasis on courts is given added support. However, affirmative efforts by legal scholars and jurists to determine the proper division of authority between the public and the private sector should not be undermined by emphasizing the failures of legislatures and bureaucracies to live up to impossible ideals, particularly given the failure of markets and courts to live up to equally unrealistic expectations. ${ }^{34}$

If policy analysis and public choice are to be constructive forces, those who import economic analysis into public law must be prepared to reorient the fields in which they study and teach. Administrative law should become more concerned with the way substantive policy is made and with reviewing the paradoxes and inconsistencies of collective choice processes. While this shift in emphasis has already begun, ${ }^{35}$ it should go much further. The focus should be less on whether all the affected interests have been heard or on whether the state is harming particular individuals, and more on the structural characteristics of the political and policy process and on the evaluation of substantive outcomes in terms of equity and efficiency.

What is needed is a broad-based, collaborative effort, by economists, lawyers and political scientists to reform administrative law. In the post-

32. See, e.g., Townsend v. Yeomans, 301 U.S. 441, 451 (1937) (legislature presumed to know needs of people); Southern Ry. v. Virginia, 290 U.S. 190, 197 (1933) ("In theory, at least, the legislature acts upon adequate knowledge after full consideration and through members who represent the entire public.").

33. Easterbrook, The Supreme Court, 1983 Term-Forward: The Court and the Economic System, 98 Harv. L. Rev. 4 (1984); Easterbrook, Statutes' Domains, 50 U. ChI. L. Rev. 533 (1983); Macey, supra note 30, at 223; Posner, Economics, Politics, and the Reading of Statutes and the Constitution, 49 U. CHr. L. REv. 262 (1982).

34. Of course, even Richard Posner recognizes that markets may fail to allocate resources efficiently. However, the chapter in his text devoted to comparing regulation with the common law considers examples that favor the common law. R. POSNER, ECONOMIC ANALYSIS OF LAW, supra note 4 , at 343-64.

35. The casebooks of S. Breyer \& R. Stewart, Administrative Law and Regulatory Policy (2d ed. 1985); R. Cass \& C. Diver, Administrattve Law: Cases and Materiais (1987); J. Mashaw \& R. Merrill, Administrative Law: The American Public Law System (2d ed. 1985); and G. Robinson, E. Gellhorn \& H. Bruff, The Administratrve Process (3d ed. 1986) do make some attempt to incorporate a social science perspective. See also W. EsKRIDGE, \& P. Frickey, Cases and Materials on Legislation: Statutes and the Creation of Public Policy (1988) (casebook in related field that incorporates material from political science and public choice). 
war period, not only has the federal government moved to regulate new areas such as worker health and safety and the environment, but social science research on substantive policy and government social choice procedures has burgeoned. The courts have made a number of awkward attempts to incorporate this new learning into their opinions but have not systematically explored its implications for judicial review of congressional and agency actions. The remainder of this Comment shows how this might be accomplished. Thus, Section III builds on existing legal scholarship to outline a new approach to judicial review of statutes and the legislative process that could improve the accountability of Congress to the public.

\section{iII. Gritiquing the legislature: Toward A New Framework STATUTE}

\section{A. Public Choice Analysis of Legislation}

Any proposal to improve the accountability of the legislative process must take a realistic view of Congress. ${ }^{36}$ Work on public choice suggests that realism consists in recognizing that reelection is a central goal of members of Congress and that citizens have poor information about the actions of legislators. Therefore, without constraints, legislators have few incentives to reveal deals that would not be obvious to superficial observers. Representatives want to claim credit for politically beneficial actions-emphasizing the positive aspects of the laws passed and downplaying the negative..$^{37}$ Both electoral challengers and fellow members of Congress may point to flaws in a law, but if the statute appears to be responding to a popular concern (drug abuse, environmental pollution, consumer protection), no one may stand to gain from a curmudgeonly critique of the statutory language or a gloomy prediction about future appropriations. ${ }^{38}$ Thus, the competitive aspects of politics, while an important check, are unlikely to provide sufficient information to voters on the implications of new statutes.

Realism also forces one to recognize that interest group bargains cannot be prevented in a representative democracy. They are the cost of voting rules that are not too heavily biased toward the status quo. ${ }^{38}$ So long as the distribution of wealth produced by private markets is not accorded

36. For an attempt to supply judges with such a view, see Davidson, What Judges Ought to Know about Lawmaking in Congress, in JUDGes AND Legislators: TOWARD InSTrTUTIONAL Comity 90 (R. Katzmann ed. 1988).

37. D. MAYHEW, supra note 19 , at 52-61 (arguing that credit-claiming is one important activity of legislators who wish to be reelected).

38. See M. Fiorins, supra note 19, at 39-49; Davidson, supra note 36, at 114 (arguing that statutes "may be internally vague, confusing, and inconsistent").

39. Majority rule, for example, gives no priority to the status quo. See supra note 27. 
some special normative status, ${ }^{40}$ one must accept the fact that political choices will help some and harm others, and people will seek to be on the winning side.

Recent legal writing on the role of the Supreme Court in reviewing legislation has articulated two sharply contrasting models of legislative behavior. The first, drawing on the public choice literature and associated with Frank Easterbrook and Richard Posner, views most statutes as bargains between conflicting groups. ${ }^{41}$ Courts should uphold the bargain supported by the legislative majority but should not go beyond the explicit language of the statute. Narrow readings are favored.

In viewing most laws as "contracts," however, these authors ignore some important lessons of public choice theory. In a legislative deal, a high proportion of affected parties need not agree to the terms. Only majority support in the legislature is needed, and even supporters may represent many people who are opposed to the new law. While third parties may also be affected by private contracts, legislation can redistribute resources in ways that private contracts cannot. There is a special need for public institutions to assure that all affected individuals at least have access to information on legislative behavior. The contractual view of statutory law held by Posner and Easterbrook fails to emphasize the importance of publicity and responsibility to the electorate in determining the proper function of judicial review. Theirs is not a true public choice analysis at all, but rather draws too glibly on private contract doctrine to interpret public actions.

At the other extreme from Posner and Easterbrook are those commentators who argue that the courts should hold the legislature to substantive standards of the public good. Courts, according to this view, should become expositors of values within government and should insist that Congress follow their lead. The substantive goal might be a wealth maximization standard, a utilitarian ideal, or an egalitarian principle, but whatever it is, courts should judge laws by it. ${ }^{42}$ Although the role of courts has seldom been considered by economists, most believe that legislation should

40. Cf. J. Meade, Efficiency, Equality and the OWnership of Property (1965) (arguing for redistributive policies); K. Wicksell, VAlue, CAPITAl AND RENT 43 (1954 \& reprint 1970) ("IN]o one, however learned or sagacious he may be, can claim for the majority of the present possessors of capital and rent a right higher than that which lies in the instinct of self-preservation. . . .").

41. See supra note 33.

42. Bennett, Mere Rationality in Constitutional Law: Judicial Review and Democratic Theory, 67 CALIF. L. REv. 1049 (1979) (unalloyed personal favor is illegitimate purpose); Mashaw, Constitutional Deregulation: Notes Toward a Public, Public Law, 54 TuL. L. REv. 849 (1980) (constitutional argument for requirement that laws serve public interest); Sunstein, Constitutionalism After the New Deal, 101 Harv. L. Rev. 421 (1987) (courts should require laws to have public-regarding purposes); Note, State Economic Substantive Due Process: A Proposed Approach, 88 YAle L.J. 1487 (1979) (laws with economic content should further ends of allocation, stabilization or distribution). 
further the substantive goal of efficiency. Some scholars have sought to design political institutions that produce this result. ${ }^{43}$

The ideal legislative process, in my view, falls between these extremes. My position can be articulated in a weak form that is closer to the legislation-as-bargain view or in a strong form that is closer to the public interest view. The weak form acknowledges the fact that much legislation is a bargain among self-interested actors; therefore, judicial review should improve the information available to those affected by the bargain. Within constitutional limits, ${ }^{44}$ the courts must accept the fact that laws passed by a majority of the legislature may harm both poorly organized groups and well-organized but politically weak groups. The courts should not try to prevent this kind of lawmaking. The aim of judicial review should, instead, be to make legislators more responsible to the electorate by assuring that information about legislative bargains is more widely available. Individuals can then decide whether to take political action and, if so, what kind. ${ }^{45}$

The strong form of my position views the ideal legislative process as one in which representatives deliberate about the public interest. ${ }^{48}$ Here, the legislature is viewed as a forum for discussing different points of view and for formulating policy that reconciles political differences. Those who engage in these debates, whether they are legislators or others trying to influence political outcomes, should use broad public interest arguments to justify their positions. Public policy analysis should play a role in helping to justify or critique proposed statutory changes. Instead of simply asserting that a bill is good for the trucking industry, supporters, if they can do so responsibly, should explain why large segments of the public will benefit as well. Despite denials by conservative public choice scholars, evidence suggests that at least some lawmaking is deliberative and that ideas and principles do play a role in the legislative process. ${ }^{47}$

In either its weak or strong form, a case can be made for a new kind of judicial review, one that imposes particular forms of statutory consistency on all legislative output. This Comment outlines a new framework statute, analogous to the Administrative Procedure Act, aimed at defining the sort of judicial intervention that might encourage deliberation and improve voters' capacity to monitor the output of congressional bargains. ${ }^{48}$

43. See, e.g., Clarke, Multipart Pricing of Public Goods, 11 Puв. Chorce 17 (1971); Tideman \& Tullock, A New and Superior Process for Making Social Choices, 84 J. Pol. Econ. 1145 (1976). 44. For a discussion of these limits, see Ackerman, Beyond Carolene Products, 98 Harv. L. REv. 713 (1985).

45. But $c f$. M. OLson, supra note 19 (discussing difficulties of organizing for collective action).

46. See Mashaw, supra note 42; Sunstein, supra note 42.

47. See J. Kingdon, Agendas, Alternatives, And Public Policies (1984); Kalt \& Zupan, Capture and Ideology in the Economic Theory of Politics, 74 AM. EcoN. REv. 301 (1984); Levine, supra note 14 , at 179 .

48. Cf. J. Ely, Democracy and Distrust 74 (1980) (arguing for related approach using constitutionally-founded review based on process by which statutes are passed). 


\section{B. Legislative Consistency}

The proposed framework statute to govern judicial review of legislative consistency does not demand the logically impossible. The results of public choice research show that global consistency across issues is extremely unlikely in a majority rule system, or indeed under any voting rule, so long as people's preferences are free to take on any values. ${ }^{49}$ Voting cycles are endemic. $^{\text {so }}$ Thus it would be inconsistent with democratic values for courts to require logical consistency in a global sense. Such a strong position would truly be counter-majoritarian. Under my proposal, in contrast, courts would look only at the properties of individual statutes. First, judges would consider whether the statute's means plausibly further its stated ends. Second, they would ask if appropriations permit the plausible pursuit of statutory purposes.

The first type of consistency-call it "internal consistency"-would be enforced by judicial insistence that statutes contain statements of purpose that could be taken seriously by the courts as reflecting legislative intent. These statements could express multiple purposes, but to the extent that purposes conflict, the introductory material should give some guidance concerning the way tradeoffs are to be made. Anything in the body of the statute that is inconsistent with the prefatory statement of purpose would be invalidated by the court. Legislators would be forced to articulate aims and to stick to them in drafting specific provisions. The courts would not engage in policy analysis when they review statutes, but they would insist that the legislators both articulate a set of purposes and consider the relationship between means and ends.

The demand for internal consistency addresses two problems. On the one hand, some statutes have overly ambitious preambles that cannot possibly be accomplished given the other goals people care about (e.g., reducing water pollution to zero, eliminating cancer risks). ${ }^{51}$ Internal consistency is designed to interject a note of realism into the preambles of such statutes and, as a consequence, to encourage a more informed debate over policy tradeoffs. On the other hand, some statutes have narrowly focused preambles (protecting the health of those who use barbers or need eye

49. See K. Arrow, supra note 15, at 46-60. The conditions Arrow places on the social ordering are stated informally at note 16 supra.

50. Some observers complain that they have never seen a voting cycle. This observation is consistent with a political system that has structured its procedures so that no political decisionmaking process can go on forever. For example, legislators commonly refuse to permit the reintroduction of an option that lost in an earlier test. Several scholars have isolated cases in which they believe a voting cycle is present in the underlying preferences. See, e.g., W. EskRIDGe \& P. FRICKEY, supra note 35, at 370-73; Riker, Arrow's Theorem and Some Examples of the Paradox of Voting, in 1 MATHEMATical Applications in Political Science (J. Glaunch ed. 1965).

51. For example, the Federal Water Pollution Control Act Amendments of 1972 have as their goal "that the discharge of pollutants into the navigable waters be eliminated by 1985," 33 U.S.C. $\S 1251(\mathrm{a})(1)(1982)$, and the Delaney Clause in the Food Additive Amendments of 1958, 21 U.S.C. $\S 321(\mathrm{~s})$ (1982), prohibits additives that cause cancer in humans or laboratory animals. 
care), but include provisions with no obvious link to these purposes (grandfather clauses, advertising bans, prohibitions on corporate ownership). ${ }^{82}$ When faced with special interest statutes, courts would only allow legislative judgments to stand if the preambles clearly stated the acts' purposes (for example, protecting existing barbers or favoring optometrists). ${ }^{.3}$

My framework proposal would also require a second kind of consistency-budgetary consistency-whose importance is increasingly obvious in a modern welfare state. Here the problem may not be evident from the statutory language. The act promises broad benefits in its statement of purpose, and it is only several years later, when appropriations are not sufficient to meet stated goals, that the inconsistency between budgetary means and statutory aims becomes clear. Legislators have an incentive to pass this sort of law because they can claim credit at the time of passage and may never be blamed for the low level of appropriations. If, however, this behavior results in judicial invalidation, the public stigma may make such behavior less politically appealing in the first place.

One justification for budgetary consistency derives from the value of an informed bargain. Both beneficiaries and taxpayers should know what has been agreed on by the legislature. Budgetary consistency would then force the legislators to clarify what they are committed to doing. Moreover, this consistency requirement could foster a deliberative process that places more weight on the formulation of public values. By forcing representatives to confront the financial consequences of their rhetoric, a more sharply focused debate will result, and Congress will be able to deliberate more meaningfully on the relationship between activist goals and fiscal means.

A budgetary consistency requirement could be beneficial without asking courts to invalidate defective laws outright. Such drastic measures would be appropriate only if after a further period of deliberation, Congress neither rewrote the statute, nor appropriated more money, nor explained

52. Many state regulatory statutes fall into this category. For example, a Virginia statute regulating pharmacists was supposed to protect the public interest. VA. CODE ANN. $\S 54-524.2$ (1950). The act contained a ban on price advertising. VA. CODE ANN. § 54-524.35 (1950). The advertising ban was struck down by the Supreme Court in Virginia State Bd. of Pharmacy v. Virginia Citizens Consumer Council, 425 U.S. 748 (1976). See also the statutes at issue in Exxon Corp. v. Governor of Md., 437 U.S. 117 (1978); Head v. New Mexico Bd. of Examiners in Optometry, 374 U.S. 424 (1963); Williamson v. Lee Optical Inc., 348 U.S. 483 (1955); Semler v. Oregon State Bd. of Dental Examiners, 294 U.S. 608 (1935).

53. My proposal resembles the type of review proposed by Macey, supra note 30 (arguing for conventional approach to statutory interpretation that looks to "plain meaning" in both statutes and legislative history and does not try to reconstruct back room bargains). Macey, however, does not go far enough. We need a stronger judicial posture that not only refuses to enforce hidden-implicit deals but also tests statutes themselves for internal consistency. Inconsistency is not recognized by Macey as a problem that requires judicial notice. He also ignores the possibility that courts may give a public interest gloss to special interest legislation that has been packaged in attractive rhetoric. Both possibilities require more than a "plain meaning" approach--the former, because there is no plain meaning; the latter, because the "plain" meaning is misleading. 
how legislative ends and financial means were more harmonious than the court's analysis suggested.

In short, while requiring internal consistency between stated purposes and statutory language may seem quite different from mandating consistency between statutory language and subsequent budgetary appropriations, both proposals actually have similar aims. Each consistency test attempts to increase the accountability of the legislature to the voting public and to improve deliberation within Congress. Each does this by requiring Congress to recognize the constraints imposed by conflicting goals and limited resources and by insisting that special interest deals, when they occur, be publicly recognized as one of a statute's purposes. The aim is to reconcile pluralist democracy and the separation of powers with an informed deliberation about means and ends.

Although my proposed statute calls for an activist federal judiciary, capable of understanding and evaluating policy arguments, it does not envision judges who seek to convert their own policy preferences into law. Instead, the statute aims to reinforce democratic representation by adding greater realism to judicial interpretation of statutes and review of the legislative process. Its approach thus is complementary to the processoriented perspective on judicial review espoused by John Ely who studies political speech, voting rights and unconstitutional classifications but does not address the possibility that legislators might mislead voters. ${ }^{34}$

\section{Gritiquing the law: The Example of Workplace Health and SAFETy Regulation}

A reformist law and economics can illuminate not only broad-based issues of government structure and performance, but also more narrowly focused policy issues of concern to administrative lawyers, legislators, and judges. Workplace health and safety regulation provides a clear-cut example of the relevance of law and economics to the work of all branches of government. Section IV(A) begins with a general analysis of the issue from a public policy perspective, a perspective that should guide responsible congressional deliberations. Next, I criticize the distributive arguments that have been central to the political debate over health and safety regulation. While redistribution is a valid statutory goal and while aid to working people is a legitimate concern of a democratic government, I argue that a well-informed policy analysis suggests that occupational health and safety regulation is a poor method of achieving these aims. Section IV(A) concludes with an outline of a policy that emphasizes the correction of market failures. With this proposal as background, Section IV(B) criticizes current legislation that regulates workplace health and safety and

54. J. ELY, supra note 48. In the course of his more detailed analyses of other issues, Ely notes that requiring clear statements of purpose would be a costly reform. Id. at 129 . 
assesses its implementation by the bureaucracy and its fate in the courts. I conclude with Justice Rehnquist's attempt to revive the nondelegation doctrine in response to congressional efforts to escape accountability for the substance of regulatory policy. Rather than obstruct the ability of Congress to delegate complex and technical matters to agencies, I argue that the statute proposed above provides a more effective framework for evaluating legislation.

\section{A. A Policy Analytic Framework}

\section{Efficient Risk Regulation}

The analysis of occupational health and safety begins with three familiar points. ${ }^{\text {s5 }}$ First, most people voluntarily take many risks in their daily lives because of the accompanying benefits. No one lives as if his or her main goal were maximizing the number of breaths taken. ${ }^{56}$ Second, people tend to be poorly informed about actual levels of risk. Many studies have documented these misperceptions and the general tendency to overestimate the probability of events that are beyond one's control while underestimating other risky possibilities. ${ }^{57}$ Third, it is often difficult to present risk assessments in ways that can be easily used by ordinary people in their daily lives.

These observations about individual behavior form a familiar starting point for an analysis of health and safety risks in the workplace. The simple economic story told by Chicagoans posits a labor market with many competing employers. If workers are informed about risks, they will demand higher wages for high risk jobs. They will also sort themselves over the available jobs depending upon their preferences toward risk. ${ }^{\mathbf{s}}$

Even in this simple competitive world, one complication must be introduced immediately. Knowing that they must compensate workers to take risks, employers would like to keep job hazards secret. Therefore, the market will then only work efficiently if potential new employees can observe the riskiness of jobs. One way such information might be provided is through a learning process. The first round of employees are uninformed,

55. For more comprehensive discussions of the issues outlined below, see J. MENDELOFF, ThE Dilemma of Toxic Substance Regulation: How Overregulation Gauses Underregulation at OSHA (1988) [hereinafter J. Mendeloff, The Dilemma]; J. Mendeloff, Regulating Safety (1979); W. Viscusi, Risk by Choice (1983).

56. W. Viscusi, supra note 55, at 1-5.

57. See, e.g., JUdGment Under UnCertainty: Heuristics and Biases (D. Kahneman, P. Slovic \& A. Tversky eds. 1982); Fischhoff, Slovic, Lichtenstein, Read \& Combs, How Safe is Safe Enough? A Psychometric Study of Attitudes Towards Technological Risks and Benefits, 9 PoL'y Sct. 127 (1978) (demonstrating complexity of individual risk judgments).

58. W. VIscusi, supra note 55, at 37-58. The evidence for this theory is not clear-cut. See Smith, Compensating Wage Differentials and Public Policy: A Review, 32 Indus. \& LAB. ReL. Rev. 339 (1979) (only risk of death is incorporated into wage differentials); Viscusi, Labor Market Valuations of Life and Limb: Empirical Evidence and Policy Implications, 26 PuB. PoL'y 359 (1978) (workers do obtain wage premiums in risky jobs). 
but after they are injured, other members of the labor force observe their injuries and illnesses and demand that the company pay a wage premium or reduce workplace hazards.

There are many reasons why this learning process will work poorly in the real world. First, many hazards take a long time to produce injuries. Second, even if they happen quickly, participants in a large labor market will not observe many of the injured. Third, the level of hazard depends on workers as well as workplaces. Some workers are more susceptible to hazards because of their genetic characteristics or their life style-for example, whether they smoke. Therefore, it may be difficult for job applicants correctly to infer their own risk by observing the harm suffered by others. Fourth, workplace conditions change with technology-so the past may be a poor guide to the future. For all these reasons, regulations that require employers to inform employees of hazards are easy to justify. The information must, however, be provided in a form that employees can understand and use to compare job market options. ${ }^{58}$

But the mere provision of information may not be sufficient for two different reasons. The first turns on the limited information-processing capacities of people, especially regarding probabilistic information. Rather than engage in a massive educational campaign, it may be more efficient to regulate workplace health and safety directly through administrative orders or incentive schemes. This justification will be especially strong when the employer's action affects all employees, the plant employs a large number of people, and most people, if informed, would assert that the benefits of added safety outweigh the costs.

A second reason why an information strategy may be inadequate concerns the production function for health and safety. Many actions employers take are "local public goods." If dust collectors are installed, they will benefit all employees on a shop floor, and if a harmless chemical is substituted for a toxic, everyone who comes in contact with the material will benefit. However, if the employees are not organized into a union, individual workers may be unwilling to modify their wage demands enough to make the health and safety investment worthwhile. If employers do not know the value workers place on safety, they may be unwilling to experiment with costly changes that may not pay off in lower wage increases or improved productivity. Established employers are especially unlikely to act if money wages are sticky downward and thus cannot be reduced in the face of an acknowledged improvement in working conditions.

There is a final argument for regulating workplace health and safety. Given the widespread existence of health insurance, welfare, and publicly

59. J. Mendeloff, Regulating Saffty, supra note 55, at 13-15; W. Viscusi, supra note 55, at 59-87; Lyndon, Information Economics and Chemical Toxicity: Designing Laws to Produce and Use Data, 87 Mich. L. REv. (1989) (forthcoming). 
subsidized health care for the poor and old, individuals do not bear all of the costs of their illnesses and injuries. Furthermore, individuals may not properly weigh the pain and suffering of their relatives and friends. Given a public commitment to redistributive policies, especially in health care, individuals may fail to take into account all the social costs of their risky employment decisions. Their insulation provides a final public policy justification for public regulation of these risks. ${ }^{60}$

\section{Inalienability and Distributive Benefits}

The efficiency arguments for risk regulation are powerful, and suggest the need for federal regulation which emphasizes the establishment of minimum standards and the provision of information. The more familiar distributive justifications for regulation (which presume that workers always benefit from stringent rules) are, however, deeply flawed. They are based on a distorted view of the way labor markets can be expected to respond to health and safety regulations.

Assume first that workers have a right to a safe workplace, and then consider the next step: Should workers be entitled to trade this safety right for higher pay, or should this right be made inalienable? Inalienability is supported by those who take an interest in workers' health but not in their overall level of well-being, and by those who do not wish to acknowledge that base wages are so low that people are willing to sacrifice health for income. Imposing costs on workers because of the squeamishness of others, however, hardly seems like good public policy, especially for a program ostensibly designed to benefit workers. A better response would be a program of redistributive taxation and subsidy that leads most people to choose improvements in health over marginal improvements in income. ${ }^{\text {B1 }}$

If, however, relative status matters to workers, and if status is measured by one's position in the ranking of money incomes, then workers may favor direct regulation. In the absence of regulation, workers are caught in a "prisoners' dilemma" and may agree to higher pay in return for accepting greater risks. If everyone does this, no one ultimately benefits. Relative positions remain unchanged. Given this possibility, most workers might wish to bind themselves not to make such deals. ${ }^{62}$ While this argument for inalienability is provocative, it requires more empirical testing. Do workers only care about relative money income? Might not workplace

60. J. Mendeloff, Regulating SAfety, supra note 55, at 12-13.

61. See also Rose-Ackerman, Inalienability and the Theory of Property Rights, 85 Colum. L. REv. 931 (1985) (proposing more general analysis of efficiency and equality justifications for inalienability rules).

62. J. Frank, Choosing the Right Pond 136-41 (1985) (making this argument in context of theory that stresses importance of relative status). 
conditions also affect relative status? Do highly paid construction workers have higher status than more poorly paid white collar workers?

Second, however one resolves the inalienability issue, one must assess the value of the right to a safe workplace, in the absence of a right to one's job or to a particular wage. As it stands, if a person holds a job with a particular employer, then he or she may not be subjected to certain hazards. Wages, however, can be adjusted to take account of these hazards, and the size of the workforce can be reduced..$^{\text {s3 }}$ In a prosperous industry, unionized workers may obtain real short-term gains if firms spend more on health and safety and cannot adjust wages under the contract. ${ }^{64}$ Over the long term, however, government regulation of workplace health and safety is unlikely to cause much redistribution. In order for workers to obtain all the benefits, regulation must impose a fixed cost on the firm that is not large enough to cause it to shut down. This will occur, however, only if the firm was earning monopoly profits before regulation was imposed and if marginal costs are unaffected. In more general cases regulation is likely to reduce employment levels and the real value of takehome pay, and to raise product prices even if workers who retain their jobs are better off. Regulation may still be desirable because workers benefit from better health and fewer accidents, but it should not be lightly presumed that the costs of regulation will be primarily borne by owners of capital and consumers.

Even workers facing employers with monopsony power may not be better off under stringent occupational health and safety rules. Such employers can make take-it-or-leave-it offers which include unhealthy and unsafe working conditions. This tactic, however, depends on poorly informed workers since well-informed workers who saw a hazard they wanted corrected would accept a pay cut in return for the increase in safety. The monopsony power of the employer should be irrelevant. Thus one would not expect health and safety regulation, by itself, to help workers in weak bargaining positions. It might even hurt them by reducing their options. The basic problem for these workers is their weak bargaining position, not the fact that they are willing to accept risks in return for higher pay.

\section{Policy Proposals}

The policy suggested by this analysis occupies a middle ground between the Chicagoans' faith in free markets and the present regulatory system under the Occupational Safety and Health Act. First, employers should be required to inform workers and job applicants of the hazards they face in the workplace. This information should be provided both in a clear and nontechnical form for workers and in the technical form necessary for in-

63. W. Viscusi. supre note 55 , at 83.

64. J. Mendeloff, Regulating Safety, supra note 55, at 32-33. 
dependent research. ${ }^{65}$ Second, the government should sponsor research designed to discover the level of risk posed by various substances, tools, capital equipment, and generic work practices. It should also sponsor research on the treatment of work-related health problems. ${ }^{66}$ Third, a subset of hazards should be restricted by regulation to avoid serious risks that most people would not plausibly pay to accept. While a full-fledged costbenefit test may be impossible to apply given the difficulty of assigning monetary values to health risks, regulatory restrictions should, at least, equalize the marginal cost of safety across occupations, and they should be set at levels that are clearly cost effective. ${ }^{67}$ The standards should be expressed in terms of health benefits to be achieved, not particular techniques or ambient levels of toxics. ${ }^{68}$ Such standards would permit employers and workers to settle on cost-effective techniques. Fourth, the agency should set a second tier of more stringent benchmark standards for some health and safety hazards. These would have a different legal status than the mandated minimal standards. The minimal standards should be firm, well-enforced requirements. In contrast, the secondary standards should be designed to give workers leverage when bargaining with employers either individually or through their unions. Employers should be required to comply with these secondary standards unless the workers agree to permit their relaxation in return for other job-related benefits. ${ }^{68}$ Workers who asserted their rights under the act could not be fired or disciplined. Employers would have to compensate them to accept hazards. Fifth, new chemical substances would be pre-screened to eliminate or control severe hazards. The pre-screening procedures would be expedited with the burden on the government to show a major risk of harm to workers. Care would be taken to be sure that new substances are not disadvantaged relative to existing substances. ${ }^{70}$ Finally, the worker compensation system

65. Lyndon, supra note 59.

66. W. Viscusi, supra note 55, at 84-87, 157-59.

67. For standard discussions of cost-benefit techniques, see E. Gramlich, Benefrt-Cost ANalysis of Government Programs (1981); E. Stokey \& R. Zeckhauser, supra note 11; D. WeImer \& A. Vining, supra note 11. For a critical view, see Tribe, Ways Not to Think About Plastic Trees: New Foundations for Environmental Law, 83 YALE L.J. 1315 (1974).

68. For an example of the controversy over the use of command and control regulation, see Latin, Ideal Versus Real Regulatory Efficiency: Implementation of Uniform Standards and 'Fine-Tuning' Regulatory Reforms, 37 StAN. L. Rev. 1267 (1985) and the critical comment on this article by Ackerman \& Stewart, Reforming Environmental Law, 37 StAN. L. REv. 1333 (1985). For a general defense of the use of incentive systems in public policy, see C. SCHultze, The PuBlic Use of THE Private INTERest (1977).

69. There is some evidence that the existing Act, although it lacks the two-tier structure proposed here, operates de facto as a bargaining chip for unions. See J. MENDELoff, REguLATING SAFETY, supra note 55 , at 16-17, 91. Mendeloffs evidence for this claim is, however, mainly indirect and circumstantial.

70. For a discussion of how the inconsistent treatment of new-versus-old technology biases investment decisions under other regulatory programs, see Huber, The Old-New Division in Risk Regulation, 69 VA. L. REv. 1025 (1983). 
should be reformed to make it operate as an insurance system that gives more incentives to employers to reduce accidents. ${ }^{\text {11 }}$

\section{B. Present Federal Policy}

The conclusions suggested by reformist policy analysis diverge significantly from the requirements of the Occupational Safety and Health Act ("the Act"). ${ }^{72}$ The points of difference occur in the language of the statute, in the way the Agency has formulated priorities and set standards, and in the courts' interpretation of the statutory language.

\section{The Act}

The Act is quite specific about procedures and quite vague about policy: Congress has given almost no guidance on the substance of health and safety regulation. The Act's purpose is "to assure so far as possible every working man and woman in the Nation safe and healthful working conditions and to preserve our human resources." ${ }^{.73}$ One way in which this is to be done is "by providing medical criteria which will assure insofar as practicable that no employee will suffer diminished health, functional capacity, or life expectancy as a result of his work experience."74 Occupational health and safety standards must be "reasonably necessary or appropriate to provide safe or healthful employment and places of employment." ${ }^{\text {"78 }}$ However, Congress has not articulated a view of how the labor market works when threats to health and safety exist nor clarified how tradeoffs between the interests of workers, employers, and customers should be made.

Beyond the vague, hortatory statutory language, the only explicit mention of standard-setting criteria is the insistence that, within two years, the Secretary of Labor shall "by rule promulgate . . . any national consensus standard, and any established Federal standard, unless he determines that the promulgation of such a standard would not result in improved safety or health for specifically designated employees." ${ }^{\text {"76 }}$ These standards are

71. See W. VISCUSI, supra note 55, at 87-92, 159-60 (discussing workers' compensation reform). This approach is in contrast to the injury tax considered by the Council of Economic Advisors and other economists when the Occupational Safety and Health Act was debated. See J. MENDELoff, Regulating SAFETy, supra note 55, at 25-31. Improvements in workers' compensation appear superior to an injury tax since the employers' payments would go to the workers. My general perspective assumes that the Occupational Health and Safety Administration should concentrate on hazards that can be regulated generically by bringing to bear general knowledge about occupational hazards. Health and safety problems that are idiosyncratic to particular workplaces and particular employees can be best handled by negotiations between workers and employers. By requiring employers to pay for harms through workers' compensation, these negotiations could be weighted in favor of workers.

72. 29 U.S.C. $\$ \$ 651-678$ (1982).

73. Id. $\S 651(\mathrm{~b})$.

74. Id. $\$ 651(\mathrm{~b})(7)$.

75. Id. $\S 652(8)$.

76. Id. $\S 655(\mathrm{a})$. 
only a first step. The Secretary can modify them in accord with procedures set out in the $\mathrm{Act}^{77}$ but is given no general guidance about how to set standards beyond that provided in the definitional section. ${ }^{78} \mathrm{~A}$ special paragraph dealing with "toxic materials or harmful physical agents" is a model of ambiguity in which qualifying phrases follow other qualifying phrases. ${ }^{79}$

But the Act is not entirely without meaning. While it does not follow the suggested policy outlined above, it does incorporate some of the ideas presented in the policy discussion. In particular, it requires disclosure of workplace hazards, ${ }^{80}$ requires standards for all serious hazards, ${ }^{81}$ permits performance standards, ${ }^{82}$ and provides for research on hazards and for the collection of statistics. ${ }^{83}$ It does not, however, have any provision for two tiers of standards, does not give guidance on setting priorities, and does not establish a pre-screening requirement. ${ }^{84}$ Therefore, if one accepts the analysis of the issue presented above, the Act's provisions are both too lax and too stringent.

\section{The Agency}

Given the Act's broad delegation, much depends on the central policymaking agency-the Occupational Safety and Health Administration

77. Id. $\S 655(\mathrm{~b})$.

78. Id. § 652(8) states that " 'occupational safety and health standard' means a standard which requires conditions, or the adoption or use of one or more practices, means, methods, operations, or processes, reasonably necessary or appropriate to provide safe or healthful employment and places of employment."

79. Id. $\S 665(\mathrm{~b})(5)$. The ambiguity of the language is indicated by the lawsuits brought under that section. See, e.g., American Textile Mfrs. Inst. v. Donovan, 452 U.S. 490 (1981); Industrial Union Dep't, AFL-CIO v. American Petroleum Inst., 448 U.S. 607 (1980); ASARCO, Inc. v. OSHA, 746 F.2d 483 (9th Cir. 1984) and cases cited therein.

80. 29 U.S.C. $\$ 657$ (c) (1982) requires employers to provide certain information to employees; however, \$664 exempts trade secrets. Under \$ 655(b)(7), regulations must include warning provisions. The Secretary of Health and Human Services must publish lists of hazards $(\$ 669(6))$, and annual reports must be prepared by both the Secretary of Labor and the Secretary of Health and Human Services. Id. $\S 675$. The rule dealing with access to employee exposure and medical records is at 29 C.F.R. $\S 1910.20$ (1987). The hazard communication (labeling) rule is at 29 C.F.R. $\S$ 1910.1200 (1987). Employers must identify chemicals and issue warnings but need not perform new tests. See Sussman, An Overview of the OSHA Hazard Communication Standard and Key Issues of Interpretation, 42 Food Drug Cosm. L.J. 307 (1987); Lyndon, supra note 59.

The Toxic Substances Control Act, 15 U.S.C. $\$ \S 2601-2629$ (1982), also requires hazard disclosure. However, it has not accumulated much useful data, has required little testing, and has kept secret much data it does have. See Lyndon, supra note 59. The National Research Council, in Toxicitry Testing: Strategies to Determine Needs and Priorities (1984), reports on the need for chemical exposure and health effects information. It concludes that, for most chemicals, information is inadequate. Id. at 125-26.

81. 29 U.S.C. § 655 (Supp. IV 1986).

82. 29 U.S.C. $\S 655(\mathrm{~b})(7)(1982)$.

83. Id. $\S \S 669,671,673$.

84. The Toxic Substances Control Act, 15 U.S.C. $\$ \S 2601,2604$ (1982), does contain pre-screening requirements that apply to workplace hazards. However, reporting requirements are weak and testing can only be ordered by the Environmental Protection Agency if an unreasonable risk exists. Haslow, The EPA and Biotechnology Regulation: Coping with Scientific Uncertainty, 95 YALE L.J. 553, 567 (1986); Lyndon, supra note 59. 
("OSHA"). ${ }^{85}$ While certain activities, such as pre-screening, are clearly beyond the statutory mandate, OSHA has considerable discretion both in setting priorities and determining standards. In general, OSHA has failed to use its policymaking freedom intelligently. In a recent pair of cogently argued books, John Mendeloff develops this thesis in detail. ${ }^{88}$

Consider safety regulation first. While Mendeloff's empirical work indicates that safety regulation has had some impact on relevant accident rates, ${ }^{87}$ the overall impact on accidents has been small, and the wholesale adoption of national "consensus" standards has led to accusations that OSHA has concentrated on trivial infractions. There is some evidence, though, that OSHA safety standards have improved the bargaining power of workers by permitting them to file complaints with the agency. Given infrequent OSHA inspections, workers can use the threat of a complaint as a bargaining chip. ${ }^{88}$ OSHA standards, therefore, may act somewhat like the second tier of standards proposed in the policy discussion. If, however, enhancement of workers' bargaining power is really the main benefit of OSHA, it should be explicitly acknowledged in the language of the statute, not permitted to occur by default. Specific policies might then be designed to further this goal.

In the regulation of toxic substances, Mendeloff argues that OSHA regulates too few hazards but overregulates the few it focuses upon. ${ }^{89}$ By setting very stringent rules for some substances, OSHA practically guarantees court challenges that will drag on for years. ${ }^{80}$ OSHA should

85. A fuller analysis would consider the role of subsidiary agencies and institutions created by the statute. The Act divides authority and creates a complex administrative structure. While primary authority is given to the Secretary of Labor, the Act creates a gaggle of quasi-independent bodies. For example, the National Institute of Occupational Safety and Health is established in the Department of Health and Human Services to do research and recommend standards to the Department of Labor. 29 U.S.C. $\S 671$ (1982). A National Advisory Committee on Occupational Safety and Health is to advise the Secretary of Labor, and the Secretary may convene other, broadly representative, committees to advise on specific hazards. Id. § 670(c). Finally, an Occupational Safety and Health Review Commission, which closely resembles an independent agency, is to hear appeals from citations issued by the Secretary and to issue orders to employers. Id. $\$ \S 659,661$.

86. See J. Mendeloff, The Dilemma, supra note 55; J. Mendeloff, Regulating Safety, supra note 55. Other analyses of OSHA's behavior are found in T. GREENWOOD, KNOWLEDGE AND Discretion in Government Regulation (1984); D. MCCaffrey, OSHA and the Politics of Health Regulation (1982); B. Mintz, OSHA: History, Law and Policy (1984); W. Viscusi, supra note 55.

87. J. Mendeloff, Regulating SAfEty, supra note 55, at 94-120. This conclusion is controversial. See the contrary results in R. SMith, The Occupational. Safety and Health Acr: Irs GoAls AND ACHIEvements (1976); Viscusi, The Impact of Occupational Safety and Health Regulations, 10 Bel. J. ECON. 117 (1979). A more recent study, however, also found that OSHA has had an impact on workplace safety. Cooke \& Gautschi, OSHA, Plant Safety Programs and Injury Reduction, 20 INDUS. REI. 245 (1981).

88. J. Mendeloff, Regulating Safety, supra note 55 , at 91.

89. J. Mendeloff, The Dilemma, supra note 55.

90. For example, the original benzene standard was issued on February 10, 1978. 29 C.F.R. § 1910.1028 (1979). The Supreme Court disallowed the rule on July 2, 1980. Industrial Union Dep't, AFL-CIO v. American Petroleum Inst, 448 U.S. 607 (1980). The cotton dust standard was issued in 1978, 43 Fed. Reg. 27,352 (1978), and upheld by the Supreme Court in 1981. American Textile Mfrs. Inst. v. Donovan, 452 U.S. 490 (1981). 
quickly put into effect, and then stringently enforce, baseline regulations for a wide range of hazards that represent well-thought-out revisions of existing consensus standards. ${ }^{91}$ Once this first step is taken, OSHA can consider raising the standards for selected hazards. In the meantime, however, the baseline would be in place and would remain so should more stringent standards be challenged in court.

The difficulty that Mendeloff has isolated in toxic substance regulation derives from the method OSHA has used to set individual standards. There are two aspects to this problem: First, the stringency of the standards; and second, the form of the regulations. Public policy techniques suggest that cost-benefit criteria should be used to determine the level of care required for employees. OSHA does not have a strong record in this regard. In its early years, the agency had little policy expertise and did not effectively use available information. ${ }^{92}$ Over time, however, executive orders requiring cost-benefit analysis have induced OSHA to expand its policy staff. ${ }^{93}$ The agency has begun to perform the required studies in spite of the obvious difficulty of measuring the value of health benefits and reductions in the risk of death. ${ }^{94}$ Unfortunately, OSHA's capacities have improved in a political climate hostile to regulation, so few major rulemakings have been undertaken. Overall, rulemaking priorities seem guided more by political than by cost-effectiveness criteria. ${ }^{95}$

Even when OSHA has engaged in policy analyses, it has typically framed its regulations in primitive command-and-control language. ${ }^{98}$ In drafting regulations, OSHA has either required particular control tech-

91. In June OSHA began a rulemaking proceeding designed to provide a wholesale revision of the standards for hundreds of chemicals. The proposal has been criticized for relying too heavily on standards developed by the private American Conference of Governmental Industrial Hygienists and for lacking enforcement strength. Nevertheless, it appears to be a constructive step. 53 Fed. Reg. 20,960 (1988); 17 O.S.H. Rep. (BNA) 1334 (Jan. 27, 1988); id. at 1376 (Feb. 3, 1988); id. at 1618 (Apr. 6, 1988); id. at 1821 (May 11, 1988); 18 O.S.H. Rep. (BNA) 19 (June 8, 1988); id. at 91 (June 15, 1988); Office of Management and Budget, Regulatory Program of the United States Government: April 1, 1988-March 31, 1989, at 297-98 (1988) thereinafter OMB STUdY 1988].

92. For a criticism of OSHA's rulemaking practices, see Nichols \& Zeckhauser, OSHA After a Decade: A Time for Reason, in CASE Studies in Regulation: Revolution and Reform 202 (L. Weiss \& M. Klass eds. 1981).

93. The most recent versions are Exec. Order No. 12,291, 3 C.F.R. 127 (1981), reprinted in 5 U.S.C. $\S 601$ at 431-34 (1982), and Exec. Order No. 12,498, 3 C.F.R. 323 (1985), reprinted in 5 U.S.C.A. \$ 601 app. at 296-97 (1988). For an overview of pre-Reagan efforts to provide executive oversight, see W. Viscusi. supra note 55, at 150-55.

94. See, e.g., OSHA Notice of Proposed Rulemaking to Revise Concrete \& Masonry Construction Safety Standards, 50 Fed. Reg. 37,543 (1985); OSHA Final Rule on Occupational Exposure to Formaldehyde, 29 C.F.R. §§ 1910, 1926 (1987).

95. This is, of course, a controversial position. For the outlines of the debate, see DeMuth \& Ginsburg, White House Review of Agency Rulemaking, 99 HARv. L. REv. 1075 (1986); Morrison, OMB Interference with Agency Rulemaking: The Wrong Way to Write a Regulation, 99 HaRv. L. Rev. 1059 (1986). Additional thoughts on the debate can be found ir THE REAGan Regulatory Strategy: AN Assessment (G. Eads \& M. Fix eds. 1984).

96. For a sample of the debate over the use of command and control regulation, see the sources cited at supra note 68 . 
niques or, at best, has focused on ambient air quality rather than workers' exposure levels. ${ }^{97}$ Engineering controls are favored over personal protective devices. ${ }^{98}$ More outcome-oriented approaches do seem to be possible under the statute, and have recently been proposed by OSHA for some hazards. ${ }^{29}$ These recent innovations should be expanded.

\section{The Courts}

\section{a. Feasibility and Policy Analysis}

Could this distinctly mediocre performance by Congress and the Agency be improved by artful judicial intervention? Maybe so, but the Supreme Court has not tried to find out. Instead, the Court has rejected the use of cost-benefit techniques by OSHA in regulating toxic substances and has uncritically adopted the questionable distributive rhetoric of some of OSHA's supporters. In its benzene and cotton dust decisions, ${ }^{100}$ the Supreme Court imposed more irrationality on OSHA than was strictly required by the statute. The Justices provided a highly formal and artificial interpretation of the statutory language, even quoting the dictionary at one point to bolster their argument. ${ }^{101}$ In setting forth their interpretation of the statute in the benzene case, they rejected the more systematic, policy-oriented view of the lower court. ${ }^{102}$

Consider how OSHA must set standards for toxic substances under the Court's rulings. ${ }^{103}$ First, it must determine which hazards create a substantial risk to health. In making this determination, the Agency may use cost-benefit criteria, but once the hazard has been placed on the agenda, using a cost-benefit test to set the level of the standard is taboo. Second, OSHA must calculate the costs of progressively more stringent standards, and must choose the one that is as stringent as possible subject to the

97. See J. Mendeloff, The Dilemma, supra note 55, at 22 (summary of ambient standards). If the ultimate aim is to improve workers' health, worker exposure is a more valid measure of the level of control than ambient air quality.

98. J. Mendeloff, The Dilemma, supra note 55, at 177-80. Personal protective devices are often much cheaper than engineering controls but are frequently opposed by workers. Workers could, however, be compensated for accepting respirators or earplugs in those situations in which such devices are cost effective.

99. The hazards include: cotton dust, 29 C.F.R. $\$ 1910$ (1987); grain elevators, 17 O.S.H. Rep. (BNA) 1227 (Jan. 6, 1988); asbestos, 15 O.S.H. Rep. (BNA) 917 (Jan. 30, 1986); ethylene oxide, 53 Fed. Reg. 11,414 (1988). See also OSHA's proposed revision of the air contaminant exposure limits. Id. at 20,960 (1988).

In an interesting switch, firms in the smelting industry argued that OSHA's rule on airborne arsenic should be overturned because OSHA had not told them specifically what technology to employ. They argued that it was "unreasonable" for them to have to develop their own compliance plans. The court of appeals rejected this argument. ASARCO, Inc. v. OSHA, 746 F.2d 483, 498 (9th Cir. 1984).

100. American Textile Mfrs. Inst. v. Donovan, 452 U.S. 490 (1981) (cotton dust); Industrial Union Dep't, AFL-GIO v. American Petroleum Inst., 448 U.S. 607 (1980) (benzene).

101. American Textile, 452 U.S. 490, 508-09.

102. American Petroleum Inst. v. OSHA, 581 F.2d 493 (5th Cir. 1978).

103. The process is described in Industrial Union Dep't, 448 U.S. 607, 640-46 (Stevens, J., concurring). 
constraint that the industry remain "viable." An OSHA standard may thus be set at a point where the marginal gain in health is small and the marginal cost is very large. The emphasis on industry viability means that very dangerous occupations in marginally profitable industries may be unregulated while other jobs may be made so safe at such a high cost that employment levels and money wages will shrink. Thus "feasibility" analysis, as envisaged by the Court, can exacerbate OSHA's tendency to both overregulate and underregulate. Such a standard-setting technique ignores the wisdom of focusing on marginal costs and benefits at all stages of the analysis.

Small wonder then that the deregulation-prone Reagan administration has avoided rulemaking in the toxic substance area. ${ }^{104}$ Once the rulemaking process is begun, the reasoning in the cotton dust case must be applied. Therefore, OSHA appears to have avoided putting items on the agenda-a decision that is not subject to judicial review.

Workplace health regulation would be stronger and more effective if the Supreme Court majority had adopted an interpretation of the statute consistent with the principles of policy analysis. An opening was provided by the lower court opinion in the benzene case: The Fifth Circuit applied a cost-benefit test by developing an analogy to the regulation of consumer product safety and the Learned Hand test in tort law. ${ }^{105}$ Only Justice Powell was willing to follow the lower court's formulation. For Powell, a

104. Office of Management and Budget, Regulatory Program of the United States Government, APRIL 1, 1987-MARCH 31, 1988, at 650 (1987) (only three substances, formaldehyde, benzene and ethylene dibromide, listed as reaching final rule stage during that period); Office of Management and Budget, Regulatory Program of the United States Government: APRIL 1, 1986-MARCH 31, 1987, at 579 (1986) (same three substances, plus asbestos, are listed in final rule category). Only the asbestos regulations were actually issued in 1986, 51 Fed. Reg. 22,612 (1986), and they lacked any controls on short-term exposures, 53 Fed. Reg. 14,029 (1988). In 1987, a benzene regulation was finally issued and has been accepted without court challenge. The benzene rule is a response to Industrial Union Dep't, 448 U.S. 607 (1980). Final OSHA Rule on Occupational Exposure to Benzene, 29 C.F.R. $\$ 1910$ (1987); see also 17 O.S.H. Rep. 995 (BNA) (Dec. 2, 1987) (steelworkers, AISI, withdraw challenges to benzene rule filed in D.C. Circuits). A rule for formaldehyde was issued in February 1988, 29 C.F.R. $\S \S 1910,1926$ (1987), but ethylene dibromide remains on OSHA's agenda. See OMB STUDY 1988, supra note 91, at 288-89. No other substances are expected to reach the final rule stage during the current year. Id. at 584 .

105. Given the similarity of the underlying issues, the Fifth Circuit concluded that:

OSHA's failure to provide an estimate of expected benefits for reducing the permissible exposure limit, supported by substantial evidence, makes it impossible to assess the reasonableness of the relationship between expected costs and benefits. This failure means that the required support is lacking to show reasonable necessity for the standard promulgated.

American Petroleum Inst. v. OSHA, 581 F.2d 493, 505 (5th Cir. 1978).

However, the Agency was not required to conduct "an elaborate cost-benefit analysis" so long as the benefits bear "a reasonable relationship" to the costs. Id. at 503. Thus the burden of proof was placed on the Agency, but the standard imposed took account of the imperfect information available.

In several cases decided before the benzene case, lower courts had found that the Consumer Product Safety Commission was required to balance benefits against costs when regulating hazardous products. The lower courts observed that the issue of workplace health and safety looks very similar to the issue of product safety. Part of the justification for this interpretation comes from the common law of torts. See Aqua Slide 'N' Dive Corp. v. Consumer Prod. Safety Comm'n, 569 F.2d 831 (5th Cir. 1978); Forester v. Consumer Prod. Safety Comm'n, 559 F.2d 774 (D.C. Cir. 1977). 
finding that the costs were commensurate with the benefits would have been sufficient to demonstrate that a significant risk existed. ${ }^{108}$ Thus he implicitly recognized that a regulation that saved very few lives but did so very cheaply would be worth pursuing. He also would have permitted OSHA to issue regulations even though the underlying data were weak, so long as OSHA made good use of what was available. ${ }^{107}$ However, he concluded, with the Fifth Circuit, that "the statute also requires the agency to determine that the economic effects of its standard bear a reasonable relationship to the expected benefits."108

Why did no other Justices join in Powell's concurrence? The answer lies deeper than the Court's formalistic approach to statutory construction. Instead, some of the Justices adopted the flawed distributive arguments that have been central to the political debate over OSHA. ${ }^{109}$ Lacking the tools of economic theory, they took congressional pronouncements at face value. Higher standards were simply assumed to benefit workers. But as we have seen, it is not obvious that worker welfare will be improved by moving beyond the level of protection suggested by cost-benefit analysis. A court that recognized this possibility could have provided a more reasoned critique of the agency's actions. ${ }^{110}$

\section{b. The Nondelegation Doctrine: Toward Legislative Consistency}

We can now step back and consider the relevance of this case to the framework approach sketched earlier. As noted previously, the Occupational Safety and Health Act has a vague and general statement of purpose. ${ }^{111}$ Concurring in Industrial Union Dep't, AFL-CIO v. American Petroleum Inst., Justice Rehnquist's suggested remedy for such statutory ambiguities was a revival of the nondelegation doctrine. Holding the Act unconstitutional would, he believed, force Congress "to reshoulder the burden of ensuring that Gongress itself make[s] the critical policy decisions."112 Rehnquist's approach thus recognizes congressional incentives to write vague statutes, but his solution is oversimplified and heavy-handed.

106. Industrial Union Dep't, AFL-CIO v. American Petroleum Inst., 448 U.S. 607, 666 (1980).

107. Id. at 666-67.

108. Id. at 667,670 .

109. In American Textile Mfrs. Inst. v. Donovan, 452 U.S. 490, 514-22, Justice Brennan quotes extensively from the rhetoric in the Congressional Record to support his position that workers benefit from stringent rules. See also Industrial Union Dep't, 448 F.2d 607, 688 (Marshall, J., dissenting) (citing legislative history to buttress similar interpretation).

110. In areas other than toxic substances, there is some evidence that this type of review may be possible under OSHA. Safety issues can still be decided on cost-benefit grounds. Courts have also appeared more hospitable to public policy arguments when the issue is method of compliance rather than the level of worker health and safety. See Donovan v. Castle \& Cooke Foods, 692 F.2d 641 (9th Cir. 1982) (hearing damage in cannery); 18 O.S.H. Rep. (BNA) 7 (June 1, 1988) (National Grain and Food Association file brief in lawsuit challenging grain elevator standard).

111. See supra text accompanying notes 73-75.

112. Rehnquist goes on to say: "It is difficult to imagine a more obvious example of Congress simply avoiding a choice which was both fundamental for the purposes of the statute and yet politi- 
While the Act is defective, Rehnquist's solution is draconian. Many regulatory issues, including occupational health and safety, are technically complex and involve difficult valuation problems. In the case of OSHA, the arguments for delegation involve both scientific complexity and the inherently difficult issue of valuing injuries, illness, and death. In contrast to Rehnquist's effort to revive the nondelegation doctrine, the basic goal of the framework statute is to use courts to improve the legislative branch's accountability to citizens. The statute is designed to achieve this goal neither by flat invalidation nor by judicial scrutiny of substance, but by scrutiny of the clarity and logical consistency of legislative means-end language. This exercise in judicial oversight does not ask courts to engage in policy analysis, but it does require them to understand and evaluate such arguments. Judges should ask a series of questions of the legislative product: Does the act clearly state its purposes, and are the statutory details consistent with these purposes? Are the costs of a policy recognized, and is the executive branch given guidance about how to make the major policy tradeoffs? Are subsequent appropriations sufficient to carry out the statutory mandate?

This perspective permits delegation when technical expertise or detailed case-by-case judgments are necessary, while at the same time insisting that Congress make critical policy choices concerning how much of society's resources (public and private) should be used to further a program's basic goals. ${ }^{113}$ Mandating internal consistency and budgetary consistency requires a genuinely progressive effort by Congress: A flawed statute might be judged both impermissibly vague, because basic policy goals are not stated concretely, and overly specific, because the agency faces constraints which restrict effective performance. ${ }^{114}$ The implications of this analysis for OSHA must await the more careful articulation of these principles by judges and legal scholars. At a minimum, however, responsible policy analysts should propose legislative alternatives to Congress that focus on the costs and distributive consequences of health and safety regulation as well as on the benefits.

\section{Conclusion}

Law and economics should be at the center of study of the modern welfare state. Today, it is at the periphery. By focusing on the common

cally so divisive that the necessary decision or compromise was difficult, if not impossible, to hammer out in the legislative forge . . ." 448 U.S. 607, 687. See also American Textile, 452 U.S. 490, 543 (Rehnquist, J., dissenting). Compare Rehnquist's position with Ely's similar argument, supra note 48 , at 131-34.

113. See, e.g., B. AcKerman \& W. HASSLER, supra note 29 (arguing for adoption of this strategy in environmental area).

114. For example, an act might state that its purpose was the highest possible level of safety and then include clauses mandating particular engineering controls that represent a high-cost method of imposing safety. 
law and by taking a generally negative view of the operation of the public sector, lawyer-economists have ceded analysis of the political-economic system to others. This Comment demonstrates that a more constructive approach is possible and even necessary. While a number of the most innovative administrative law scholars have made a beginning, a much more substantial reform of the field is required. Economists, policy analysts, and political scientists should actively collaborate with public lawyers on pedagogical and scholarly projects. Integration should occur both at the level of high theory, where the underlying structures of the state are at issue, and at the level of concrete policy, where detailed, fact-bound analyses are essential.

Scholarly reorientation, moreover, should be only part of a larger process of administrative law reform. To provoke the kind of discussion that is required, I have argued for a new framework statute for the administrative state that concentrates on the accountability of Congress rather than on the behavior of agencies. Courts and the legal profession have been too ready to view the legislature as an unexamined black box whose work is presumptively valid if no explicit constitutional guarantees are violated. In contrast, modern work on public choice and public policy points to a new kind of judicial review, one that focuses on the weaknesses of representative lawmaking without asking judges to impose their own substantive policy views on the nation. The challenge is to take seriously the possibility of procedural reforms that can improve democratic accountability.

But it makes little sense to argue about such fundamental reforms in the abstract. I have tried to suggest the benefits of the framework approach by a study of occupational health and safety policy. This brief sketch sought to accomplish two tasks. First, it tried to demonstrate how a grasp of economic reasoning can help clarify vexing issues in health and safety law. Second, it showed how the judicial failure to examine the means-end connection in regulatory statutes can reinforce congressional incentives to hide behind vague, but politically pleasing, rhetoric.

In this Comment I have provided only an overview of a proposed general framework statute and of occupational safety and health policy. I aim by these examples to chart the direction that research should take. If broad-based fundamental inquires can intersect with studies of particular problems, each will be enriched by the insights of the other. The result will be an administrative law that is stronger, both theoretically and empirically, than the present court-centered paradigm. 